\title{
Agri-food supply chain and disruptions due to COVID-19: effects and strategies
}

\author{
Saurabh Sid ${ }^{1}$, Rahul S Mor ${ }^{1}$, Anupama Panghal ${ }^{2}$, Dinesh Kumar ${ }^{3}$, Vijay Kumar Gahlawat ${ }^{4}$ \\ ${ }^{1}$ Department of Food Engineering, National Institute of Food Technology Entrepreneurship and Management, Kundli, Sonepat, \\ India. \\ ${ }^{2}$ Department of FBM \& ED, National Institute of Food Technology Entrepreneurship and Management, Kundli, Sonepat, India. \\ ${ }^{3}$ Department of Production \& Industrial Engineering, National Institute of Technology, Jamshedpur, India. \\ ${ }^{4}$ Department of Basic \& Applied Science, National Institute of Food Technology Entrepreneurship and Management, Kundli, \\ Sonepat, India.
}

How to cite: Sid, S., Mor, R.S., Panghal, A. et al. (2021), "Agri-food supply chain and disruptions due to COVID-19: effects and strategies", Brazilian Journal of Operations \& Production Management, Vol. 18, No. 2, e20211148. https://doi.org/10.14488/BJOPM.2021.031

\section{ABSTRACT}

Goal: The novel coronavirus (COVID-19) pandemic has severely affected the global economies. It has a considerable effect on the agri-food economy and the linking food supply chains. The entire agrifood sector needs more attention because the concept of 'work from home' does not work here, and life cannot move even a single step without food. This paper offers a future agri-food sector perspective amid the COVID-19 pandemic.

Design / Methodology / Approach: This paper explores the short-term and long-term effects of the COVID-19 pandemic on agri-food supply chains (AFSCS) based on the available information. The regulatory mechanisms taken by different government agencies, NGOs, and the food industry to manage the demand \& supply disruptions are also discussed.

Results: The detailed effect analysis of the COVID-19 on agri-food supply chains and remedial strategies are conducted for different interfaces of AFSC, viz. production, handling \& storage, processing \& packaging, distribution \& marketing, consumption, etc.

Limitations of the investigation: Given the research area's novelty, it may take enormous time to fully assess the current pandemic (COVID-19) effect on agri-food and its allied sectors.

Practical implications: This paper would help the agri-food industry and the authorities assess the effect of COVID-19 on the agri-food sector.

Originality/Value: This paper significantly contributes to new research directions and views for the AFSC and disruptions due to the COVID-19 pandemic.

Keywords: COVID-19 Pandemic; Agri-Food Sector; Supply Chain Disruption; Food Supply Chain.

\section{INTRODUCTION}

Given the ongoing COVID-19 pandemic, a global wake-up call has helped India cope up at an early stage, but it necessitates continuing efforts to get back on the right track in almost all sectors. The authorities worldwide have restricted their international and local movements with strict nationwide lockdowns as a precautionary measure to this pandemic (Galanakis, 2020). Most of the nations, including India, are now recording a rising number of COVID-19 infected cases. In response, there is a strict nationwide movement lockout since March 23, 2020, in India to stop the spread of this deadly virus. The restrictions are adversely affecting all aspects of the Indian economy, especially the agri-food economy, which is 96 percent reliant

Financial support: None.

Conflict of interest: The authors have no conflict of interest to declare.

Corresponding author: dr.rahulmor@gmail.com

Received: 13 January 2021.

Approved: 26 March 2021.

Editor: Syed Abdul Rehman Khan. 
on the private sector. Thus, the linking FSCs are also not immune to this slowdown (Reardon et al., 2020). A significant increase in demand for the commonly shelf-stable food commodities is observed due to a few exemptions in movement and the rumors leading to panic buying and stockpiling behavior of customers and hence, stock-out of these products (Kamble and Mor, 2021; Troskie, 2020). The loss of income to a significant section of Indian society is also favoring this attitude, and as a result, food prices are rising sharply. Government agencies and some NGOs work continuously to compensate for this loss and maintain a regular supply of these prime necessity products. India's government has released INR 1.7 lakh crores to the different states, seeking funds for the poor and migratory workers (Ranjith and Varma, 2020). Indian food economy, which is 85 percent dependent on micro, small, and medium-sized enterprises (MSMEs), the mega relief economic package of INR 20 lakh crore (about 10 percent of Indian GDP) is announced by the honorable prime minister of India dated May 12, 2020. This package supports the related agri-food farmers, laborers, cottage industries, and middle-class people. There is a massive risk for agricultural and food security because 92 percent of the food consumed is purchased from FSCs and is provided to the consumer through the private sector. There need proper FSC planning and management to avoid the food crisis due to COVID-19 (Reardon et al., 2020; Stauffer et al., 2018; Zurayk, 2020; Ivanov and Dolgui, 2020; Carberry and Padhee, 2020).

Thus, this paper unfolds the possible short-term and long-term effects of the COVID-19 pandemic on FSCs concerning a balance among the demand and supply based on data accessible to date. The demand-side assessment takes into action the abrupt shift in food procuring patterns \& eating behavior and the public's panic purchasing attitude. The supplyside evaluation drafts the disturbance within and across border transportation, workforce shortage, etc. (Hobbs, 2020; Sharma et al., 2020). The negative aspect of this disaster is more dominant than positive, and possible remedial policies and strategies to achieve effectiveness in FSCs are discussed. The rest of the paper is organized as follows. Section 2 introduces AFSCs; section 3 presents the detailed effect analysis of COVID-19 on AFSCs and remedial strategies for each stage of AFSC. Section 4 concludes the paper's outcome, followed by the limitations and future research directions in the area.

\section{AGRI-FOOD SUPPLY CHAINS}

AFSC is the complex network of linking distribution channels from 'farm to the fork'. Managing AFSC includes a structured way of controlling the product flow from the primary manufacturer to the end consumer (Bhatia and Janardhana, 2020; Mor et al., 2018; Khan and $\mathrm{Yu}, 2019)$. India finds itself when more brainstorming and restructuring are immediately needed to achieve greater efficiency in the AFSCs for meeting the unexpected rising demands of specific products. Forsido et al. (2020) quantifies five significant stages of the FSC, which need to be managed instantly, i.e., production, processing \& packaging, handling \& storage, distribution \& marketing, and consumption. A dramatic change in the food processing sector is observed during this pandemic, including market modernization, shortened product shelflife, technical advances, and consumer demand diversification. Companies participating and collaborating under such FSC practices have to deal with several threats that need to be managed aptly. The increasing concern about food nutrients, increased interest in their safe packaging, freshness, and demand for some specific food products, including immunityboosting products, need more attention throughout the supply chain flow. Coherent measures are also required where markets can play a worthy role, and private capital funding can be stepped-up. Since the FSCs offer a connection between primary producers and endconsumers through mediators, an effective supply chain analysis along with the green practices in their management can resolve this substantial economic loss to FSCs (Yu et al., 2021; Khan et al., 2020). The different stages are elaborated in the following sections.

\section{ANALYSIS AND REMEDIAL STRATEGIES}

The detailed effect analysis of the COVID-19 on agri-food supply chains and remedial strategies is conducted and mentioned in the following sub-sections. 


\subsection{Production}

The production of raw-produce is the first stage of FSCS, and the largest agri-rural workforce employer in the country appears to be less affected directly, but its indirect effects are worst. Although about 70 percent of the farm laborers are locally available, restricted movements and social distancing have increased the labor shortage at the production stage, leading to crop failure (Larue, 2020). The farmers involved in growing grapes in Pune's western city were forced to help student volunteers harvest their crops. Consequently, a prominent Indian farmer's group has demanded a relief package of INR 1.5 lakh crores for themselves from the concerned government agencies (Toppo, 2020). There seems a risk of COVID-19 eruption in rural areas due to the improper monitoring systems of returning laborers.

Additionally, these workforces will penetrate in casual rural non-farm employment (RNFE) activities, which engage about 39 percent of rural women and is responsible for 61 percent of Indian rural income (Chand et al., 2017; D'Souza et al., 2020). Since RN-FE is linked directly or indirectly with the agri-food sector, this will also affect the AFSCs. Further, the Indian economy is composed of approx. 80 percent of non-grain food is fed mainly through perishable FSCs. Other indirect effects consist of decreasing demand and export instability of perishable products like milk, fish, chicken, vegetables, etc., due to the change in customers' food purchasing and eating behavior due to limited earnings.

Further, amid this crisis, the farmers are not getting agricultural inputs timely, and hence, they may find difficulties in preparing and conserving quality seeds for the next season. The concern regarding the availability of protective equipment and safety gloves is also hindering livestock animals' productivity. There is a need to circulate different low-cost harvesting technologies throughout the country with other farm machinery banks. Regular energy supply and information regarding farm machinery usage are also required to make the farmers aware of such machinery and technology. It will also help them cope with such situations in the future. A brief of short and long-term impacts, along with likely remedies, is shown in Table 1.

Table 1. Effects and remedial strategies: Production

\begin{tabular}{|c|c|c|c|c|}
\hline Factors & $\begin{array}{l}\text { Short-term } \\
\text { impact }\end{array}$ & $\begin{array}{l}\text { Remedial } \\
\text { strategies }\end{array}$ & $\begin{array}{l}\text { Long-term } \\
\text { impact }\end{array}$ & $\begin{array}{l}\text { Remedial } \\
\text { strategies }\end{array}$ \\
\hline \multirow{6}{*}{$\begin{array}{l}\text { Agri-products } \\
\text { handiness and } \\
\text { availability }\end{array}$} & $\begin{array}{l}\text { - Imports and } \\
\text { circulation }\end{array}$ & $\begin{array}{l}\text { Promotion of } \\
\text { peri-urban Agri } \\
\text { and RN-FE } \\
\text { activities }\end{array}$ & $\begin{array}{l}\text { · Farm } \\
\text { production } \\
\text { decline }\end{array}$ & $\begin{array}{l}\text { - Development of } \\
\text { local infrastructure }\end{array}$ \\
\hline & · Delay in supply & $\begin{array}{l}\text { Safe and efficient } \\
\text { distribution of agri- } \\
\text { equipment, seeds, } \\
\text { fertilizer, and } \\
\text { pesticides }\end{array}$ & $\begin{array}{l}\text { A sharp rise in } \\
\text { food } \\
\text { commodity } \\
\text { prices }\end{array}$ & $\begin{array}{l}\text { - Efficient } \\
\text { government } \\
\text { policies to } \\
\text { purchase and } \\
\text { circulate food }\end{array}$ \\
\hline & $\begin{array}{l}\text { - Lethargic } \\
\text { system }\end{array}$ & $\begin{array}{c}\text { - Involvement of } \\
\text { the private sector } \\
\text { and local people in } \\
\text { transportation }\end{array}$ & $\begin{array}{l}\text { Agri-inputs } \\
\text { shortage }\end{array}$ & $\begin{array}{c}\text { Encouragement of } \\
\text { agri-based } \\
\text { entrepreneurial } \\
\text { activities }\end{array}$ \\
\hline & & $\begin{array}{l}\text { Focus on agri- } \\
\text { inputs import }\end{array}$ & $\begin{array}{c}\text { · Food } \\
\text { insecurity }\end{array}$ & $\begin{array}{c}\text { - Incentives to small } \\
\text { agribusiness }\end{array}$ \\
\hline & & $\begin{array}{c}\text { - Increase in access } \\
\text { points }\end{array}$ & & $\begin{array}{l}\text { - Proper saving and } \\
\text { judicial investments }\end{array}$ \\
\hline & & $\begin{array}{c}\text { Provision of } \\
\text { subsidy }\end{array}$ & & \\
\hline $\begin{array}{l}\text { Agricultural } \\
\text { extension }\end{array}$ & $\begin{array}{c}\text { B Breakdown of } \\
\text { extension } \\
\text { services, such as }\end{array}$ & $\begin{array}{l}\text { Digital and } \\
\text { remote } \\
\text { communication }\end{array}$ & $\begin{array}{l}\text { Reduced field } \\
\text { and farm } \\
\text { production }\end{array}$ & $\begin{array}{c}\text { - Development of } \\
\text { web/app/GIS-based } \\
\text { technology }\end{array}$ \\
\hline
\end{tabular}


Table 1. Continued...

\begin{tabular}{|c|c|c|c|c|}
\hline Factors & $\begin{array}{c}\text { Short-term } \\
\text { impact }\end{array}$ & $\begin{array}{l}\text { Remedial } \\
\text { strategies }\end{array}$ & $\begin{array}{l}\text { Long-term } \\
\text { impact }\end{array}$ & $\begin{array}{l}\text { Remedial } \\
\text { strategies }\end{array}$ \\
\hline \multirow[t]{6}{*}{$\begin{array}{l}\text { scheme and } \\
\text { activity }\end{array}$} & $\begin{array}{l}\text { training, testing, } \\
\text { demonstrating, } \\
\text { etc. }\end{array}$ & & & \\
\hline & $\begin{array}{c}\cdot \text { Restricted } \\
\text { advertisement of } \\
\text { advanced } \\
\text { technologies }\end{array}$ & $\begin{array}{l}\text { - Engagement of } \\
\text { local model } \\
\text { farmers for } \\
\text { extension services }\end{array}$ & $\begin{array}{c}\text { - Inability to } \\
\text { operate } \\
\text { machinery }\end{array}$ & $\begin{array}{l}\text { - Upgradation of } \\
\text { private extension } \\
\text { systems }\end{array}$ \\
\hline & & $\begin{array}{c}\cdot \text { Revision of } \\
\text { extension policies }\end{array}$ & & $\begin{array}{l}\text { Strengthening of } \\
\text { the disaster } \\
\text { prevention } \\
\text { department }\end{array}$ \\
\hline & & $\begin{array}{l}\text { · Tax-waiver } \\
\text { schemes on Agri } \\
\text { machinery }\end{array}$ & & \\
\hline & · Labor shortage & $\begin{array}{c}\text { The safe and } \\
\text { watchful labor } \\
\text { movement }\end{array}$ & $\begin{array}{c}\text { - Reduction in } \\
\text { productivity of } \\
\text { labor-intensive } \\
\text { agri-firms }\end{array}$ & $\begin{array}{l}\text { · Focused } \\
\text { advertisement for } \\
\text { small and handy } \\
\text { agri-machineries }\end{array}$ \\
\hline & $\begin{array}{l}\text { Risk of COVID- } \\
19 \text { eruption due } \\
\text { to labor } \\
\text { migration }\end{array}$ & $\begin{array}{l}\text { - The mandatory } \\
\text { quarantine period } \\
\text { for migrant labor }\end{array}$ & $\begin{array}{l}\text { Shrinking } \\
\text { agribusiness } \\
\text { and foreign } \\
\text { exchange }\end{array}$ & $\begin{array}{c}\text { - Promoting RN-FE } \\
\text { activities to employ } \\
\text { labor during off- } \\
\text { days }\end{array}$ \\
\hline \multirow{3}{*}{$\begin{array}{l}\text { Workforce } \\
\text { movement }\end{array}$} & $\begin{array}{l}\text { Decline in } \\
\text { exports }\end{array}$ & $\begin{array}{l}\text { - Appropriate } \\
\text { prevention } \\
\text { measures during } \\
\text { farm activities }\end{array}$ & & $\begin{array}{c}\text { - Establishment and } \\
\text { promotion of } \\
\text { contract farming }\end{array}$ \\
\hline & & $\begin{array}{l}\text { - Living quarters } \\
\text { establishment for } \\
\text { emergencies }\end{array}$ & & \\
\hline & & $\begin{array}{c}\text { - Regular payment } \\
\text { to labor }\end{array}$ & & \\
\hline \multirow{2}{*}{$\begin{array}{l}\text { Fuel and energy } \\
\text { accessibility and } \\
\text { affordability }\end{array}$} & \multirow{2}{*}{$\begin{array}{l}\text { Fuel scarcity for } \\
\text { Agri machinery }\end{array}$} & \multirow{2}{*}{$\begin{array}{l}\text { Provision of fuel } \\
\text { reservations at } \\
\text { petrol pumps for } \\
\text { Agri machinery }\end{array}$} & \multirow{2}{*}{$\begin{array}{l}\text { Fuel scarcity } \\
\text { for Agri } \\
\text { machinery }\end{array}$} & $\begin{array}{c}\text { Ensuring } \\
\text { sustainable energy } \\
\text { supply }\end{array}$ \\
\hline & & & & $\begin{array}{l}\text { · Promoting } \\
\text { renewable energy } \\
\text { operated farm } \\
\text { machinery }\end{array}$ \\
\hline \multirow{3}{*}{$\begin{array}{l}\text { Pastoral and } \\
\text { daily wage } \\
\text { workers } \\
\text { movement }\end{array}$} & $\begin{array}{c}\text { Risk of COVID- } \\
19 \text { pandemic } \\
\text { outbreak }\end{array}$ & $\begin{array}{l}\text { - Awareness } \\
\text { campaigns, } \\
\text { restricted } \\
\text { movements, } \\
\text { food/water } \\
\text { facilities }\end{array}$ & \multirow{3}{*}{$\begin{array}{l}\cdot \text { Stressed } \\
\text { environment } \\
\text { among public }\end{array}$} & $\begin{array}{c}\text { Provision of local } \\
\text { employment }\end{array}$ \\
\hline & $\begin{array}{l}\text { - A starvation } \\
\text { situation may } \\
\text { come }\end{array}$ & $\begin{array}{l}\text { - Providing the } \\
\text { source of earning }\end{array}$ & & $\begin{array}{c}\cdot \text { Local } \\
\text { infrastructure } \\
\text { development }\end{array}$ \\
\hline & & $\begin{array}{l}\text { - Government } \\
\text { incentives }\end{array}$ & & \\
\hline $\begin{array}{c}\text { Local } \\
\text { administration }\end{array}$ & $\begin{array}{l}\text { - Resources } \\
\text { diversion }\end{array}$ & $\begin{array}{l}\text { Proper tasks } \\
\text { allotment to } \\
\text { various } \\
\text { stakeholders }\end{array}$ & $\begin{array}{l}\text { · Fewer } \\
\text { resources for } \\
\text { agri-food } \\
\text { businesses }\end{array}$ & $\begin{array}{l}\text { - Budget allotment } \\
\text { and engagement of } \\
\text { govt. bodies }\end{array}$ \\
\hline
\end{tabular}


Table 1. Continued...

\begin{tabular}{|c|c|c|c|c|}
\hline Factors & $\begin{array}{l}\text { Short-term } \\
\text { impact }\end{array}$ & $\begin{array}{l}\text { Remedial } \\
\text { strategies }\end{array}$ & $\begin{array}{l}\text { Long-term } \\
\text { impact }\end{array}$ & $\begin{array}{l}\text { Remedial } \\
\text { strategies }\end{array}$ \\
\hline & $\begin{array}{l}\text { Coordination } \\
\text { failure among } \\
\text { different } \\
\text { stakeholders }\end{array}$ & $\begin{array}{l}\text { Effective decision- } \\
\text { making and } \\
\text { communication } \\
\text { systems at } \\
\text { different levels }\end{array}$ & $\begin{array}{l}\text { Reduction in } \\
\text { raw-produce }\end{array}$ & $\begin{array}{l}\text { Facilitating } \\
\text { agricultural } \\
\text { activities }\end{array}$ \\
\hline & & & & $\begin{array}{l}\text { Effective decision- } \\
\text { making and } \\
\text { communication } \\
\text { systems }\end{array}$ \\
\hline \multirow{3}{*}{$\begin{array}{l}\text { Service/support } \\
\text { sector }\end{array}$} & $\begin{array}{l}\text { Budgeting for } \\
\text { agri-food } \\
\text { production }\end{array}$ & $\begin{array}{l}\text { Promotion of } \\
\text { rural financing and } \\
\text { planning of } \\
\text { NGOs/Coop. } \\
\text { activities }\end{array}$ & $\begin{array}{l}\text { - Lack of fronts } \\
\text { for raw- } \\
\text { produce, } \\
\text { bankrupting of } \\
\text { financing } \\
\text { bodies }\end{array}$ & $\begin{array}{c}\text { - Focus on agri-food } \\
\text { oriented } \\
\text { banks/insurance } \\
\text { agencies }\end{array}$ \\
\hline & $\begin{array}{l}\cdot \text { Restricted } \\
\text { movements of } \\
\text { NGOs/Coop. } \\
\text { societies }\end{array}$ & $\begin{array}{l}\text { Effective virtual } \\
\text { communication }\end{array}$ & $\begin{array}{l}\text { - Overburden } \\
\text { and shrinkage } \\
\text { of NGOs and } \\
\text { Coop. societies }\end{array}$ & $\begin{array}{l}\cdot \text { Resource } \\
\text { mobilization for } \\
\text { NGOs and Coop. } \\
\text { agencies }\end{array}$ \\
\hline & $\begin{array}{l}\text { - Issues with } \\
\text { collaborative } \\
\text { work approach } \\
\text { of agri-food } \\
\text { agencies \& } \\
\text { farmers }\end{array}$ & $\begin{array}{c}\text { Awareness } \\
\text { among farmers, } \\
\text { local } \\
\text { administration, } \\
\text { and collaborating } \\
\text { bodies }\end{array}$ & $\begin{array}{c}\cdot \text { Lack of } \\
\text { coordination }\end{array}$ & $\begin{array}{c}\text { Proper } \\
\text { coordination } \\
\text { among farmers and } \\
\text { Agri agencies and }\end{array}$ \\
\hline \multirow{2}{*}{$\begin{array}{c}\text { Wildlife } \\
\text { incorporation }\end{array}$} & \multirow{2}{*}{$\begin{array}{l}\text { - Inapt wildlife } \\
\text { control in the } \\
\text { field }\end{array}$} & $\begin{array}{l}\text { Coordinated } \\
\text { effort along with } \\
\text { apt prevention } \\
\text { measures }\end{array}$ & $\begin{array}{l}\text { Loss of crop a } \\
\text { field }\end{array}$ & \multirow{2}{*}{$\begin{array}{l}\text { Arrangements like } \\
\text { wire and electric } \\
\text { fencing }\end{array}$} \\
\hline & & $\begin{array}{l}\text { - Usage of } \\
\text { natural/homemade } \\
\text { repellents }\end{array}$ & $\begin{array}{l}\text { · Food } \\
\text { insecurity }\end{array}$ & \\
\hline $\begin{array}{l}\text { Research and } \\
\text { development } \\
\text { activity }\end{array}$ & $\begin{array}{l}\text { - Disrupted R\&D } \\
\text { activity } \\
\text { - Improper } \\
\text { resource } \\
\text { utilization and } \\
\text { budget diversion }\end{array}$ & $\begin{array}{l}\text { · Finding an } \\
\text { alternative way to } \\
\text { complete ongoing } \\
\text { R\&D activities } \\
\text { - Development of } \\
\text { rapid response } \\
\text { programs }\end{array}$ & $\begin{array}{c}\text { · Delay in } \\
\text { technology } \\
\text { development }\end{array}$ & $\begin{array}{l}\text { Promoting agri- } \\
\text { food based } \\
\text { research and } \\
\text { technology } \\
\text { development } \\
\text { activities }\end{array}$ \\
\hline
\end{tabular}

\subsection{Handling and Storage}

The research studies depict that the handling and storage share a significant portion as postharvest losses among the one-third of food wastage in FSCs globally (Food and Agriculture Organization, 2019; Yahia et al., 2019). The movement restrictions have further hampered the whole handling and storage operations, leading to the wastage of perishable foods. A massive loss of vegetables is now coming to notice, such as the harvested bell pepper and cucumbers are left to get rotten in Haryana. Further, Asia's largest onion trade business in Maharashtra also found it challenging to handle the harvested onion in the absence of transportation across the country. Tons of vegetables and fruits are decaying in Delhi's Azadpur Mandi, the country's largest agri-food market (Abhishek et al., 2020). The losses in horticulture and floriculture for order cancellation also lead to an economic imbalance. Even a significant loss for low-perishable grains is observed in the absence of circulation and inappropriate storage 
techniques. The food grains in warehouses are getting waste due to fungi development, damage by insects and pests, and food made available for eating/purchasing as happened in France and UK (Phillipson et al., 2020). Further, a needs to introduce low-cost techniques like evaporative coolers and crates in the system and hermetic bags for proper storage along with proper follow-ups of first-in, first-out rules (FIFO). And one should focus on solar operated cold storage throughout the nation to avoid such types of problems in the future (World Health Organization, 2020; UN News 2020; Belhadi et al., 2020). A brief tabulated form of the impacts and remedial actions on handling and storing AFSCs is enlisted in Table 2.

Table 2. Effects and remedial strategies: Handling and Storage

\begin{tabular}{|c|c|c|c|c|}
\hline Factors & $\begin{array}{c}\text { Short-term } \\
\text { impact }\end{array}$ & $\begin{array}{l}\text { Remedial } \\
\text { strategies }\end{array}$ & Long-term impact & $\begin{array}{l}\text { Remedial } \\
\text { strategies }\end{array}$ \\
\hline \multirow{4}{*}{$\begin{array}{l}\text { Inefficient } \\
\text { storage } \\
\text { technology } \\
\text { loss }\end{array}$} & $\begin{array}{l}\text { Inappropriate } \\
\text { storage infra }\end{array}$ & $\begin{array}{l}\text { - Promotion of } \\
\text { public-private } \\
\text { partnerships for } \\
\text { food storage } \\
\text { infra }\end{array}$ & $\begin{array}{c}\text { - Grain wastage due } \\
\text { to inappropriate } \\
\text { storage }\end{array}$ & $\begin{array}{l}\text { - Promoting the } \\
\text { Ethylene } \\
\text { management of } \\
\text { perishable foods }\end{array}$ \\
\hline & $\begin{array}{l}\text { - Lack of cold } \\
\text { storage } \\
\text { technology in } \\
\text { remote areas }\end{array}$ & $\begin{array}{l}\text { The building of } \\
\text { temporary } \\
\text { warehouses }\end{array}$ & $\begin{array}{c}\text { - Lack of cold storage } \\
\text { technology in remote } \\
\text { areas }\end{array}$ & $\begin{array}{c}\text { - The building of } \\
\text { community/large } \\
\text { warehouse }\end{array}$ \\
\hline & $\begin{array}{l}\text { High loss of } \\
\text { perishable } \\
\text { products }\end{array}$ & $\begin{array}{l}\text { Promoting low- } \\
\text { cost handling \& } \\
\text { storage } \\
\text { equipment }\end{array}$ & $\begin{array}{l}\cdot \text { High loss of } \\
\text { perishable products }\end{array}$ & $\begin{array}{l}\text { · Agri-food } \\
\text { processing } \\
\text { industries, } \\
\text { institutes, etc. } \\
\text { should come } \\
\text { forward to setup } \\
\text { postharvest } \\
\text { storage and } \\
\text { handling } \\
\text { technology }\end{array}$ \\
\hline & & $\begin{array}{l}\text { - Promotion of } \\
\text { solar operated } \\
\text { cold storage } \\
\text { technology and } \\
\text { plants }\end{array}$ & & $\begin{array}{l}\text { Promoting } \\
\text { private } \\
\text { investments }\end{array}$ \\
\hline \multirow[t]{2}{*}{$\begin{array}{l}\text { Stockpiling } \\
\text { issue }\end{array}$} & \multirow[t]{2}{*}{$\begin{array}{l}\text { Deterioration in } \\
\text { food quality }\end{array}$} & \multirow{2}{*}{$\begin{array}{l}\text { · Ensuring } \\
\text { handiness and } \\
\text { timely availability } \\
\text { of food products }\end{array}$} & $\begin{array}{l}\text { Deterioration in } \\
\text { food quality }\end{array}$ & $\begin{array}{l}\text { - Maintaining } \\
\text { food quality } \\
\text { through the latest } \\
\text { technologies, viz. } \\
\text { Hermetic bags, } \\
\text { cold storage }\end{array}$ \\
\hline & & & High costly products & $\begin{array}{l}\text { Buying need- } \\
\text { based products } \\
\text { to minimize } \\
\text { stockpiling }\end{array}$ \\
\hline \multirow{2}{*}{$\begin{array}{l}\text { Losses due to } \\
\text { workforce } \\
\text { shortage }\end{array}$} & $\begin{array}{l}\cdot \text { Hampered } \\
\text { harvesting }\end{array}$ & $\begin{array}{l}\text { - Maintaining a } \\
\text { quarantine } \\
\text { period for } \\
\text { migrant labor }\end{array}$ & \multirow{2}{*}{$\begin{array}{l}\text { Barriers to the } \\
\text { seasonal labor } \\
\text { movement }\end{array}$} & \multirow{2}{*}{$\begin{array}{l}\text { - Ensuring the } \\
\text { safe and watchful } \\
\text { movement during } \\
\text { packing and } \\
\text { storage of food } \\
\text { products }\end{array}$} \\
\hline & · Handling issues & $\begin{array}{c}\text { · Following } \\
\text { appropriate } \\
\text { prevention } \\
\text { measures during } \\
\text { farm activities }\end{array}$ & & \\
\hline
\end{tabular}




\begin{tabular}{|c|c|c|c|c|}
\hline Factors & $\begin{array}{l}\text { Short-term } \\
\text { impact }\end{array}$ & $\begin{array}{l}\text { Remedial } \\
\text { strategies }\end{array}$ & Long-term impact & $\begin{array}{l}\text { Remedial } \\
\text { strategies }\end{array}$ \\
\hline & & $\begin{array}{c}\text { P Plan for } \\
\text { emergency-living } \\
\text { quarters }\end{array}$ & & \\
\hline \multirow{2}{*}{$\begin{array}{l}\text { Transport } \\
\text { restriction } \\
\text { losses }\end{array}$} & \multirow{2}{*}{$\begin{array}{l}\text { Most prominent } \\
\text { effect on } \\
\text { perishable agri- } \\
\text { food products }\end{array}$} & $\begin{array}{l}\text { Promoting food } \\
\text { processing } \\
\text { activities to avoid } \\
\text { wastages }\end{array}$ & \multirow{2}{*}{$\begin{array}{l}\text { - Most prominent } \\
\text { effect on perishable } \\
\text { Agri products }\end{array}$} & $\begin{array}{l}\text { Promoting food } \\
\text { processing } \\
\text { activities to avoid } \\
\text { wastages }\end{array}$ \\
\hline & & $\begin{array}{l}\cdot \text { Local } \\
\text { consumption of } \\
\text { perishable food }\end{array}$ & & $\begin{array}{l}\text {. A safe } \\
\text { movement to the } \\
\text { market should be } \\
\text { promoted. }\end{array}$ \\
\hline \multirow{2}{*}{$\begin{array}{c}\text { Order } \\
\text { cancellation } \\
\text { loss }\end{array}$} & $\begin{array}{l}\text {. Reduced } \\
\text { customer demand } \\
\text { leads to shuffling } \\
\text { of handling and } \\
\text { storage systems }\end{array}$ & $\begin{array}{l}\text { Promoting } \\
\text { locally available } \\
\text { food products }\end{array}$ & - Unemployment, and & \multirow{2}{*}{$\begin{array}{c}\text { - Promoting the } \\
\text { entrepreneurial } \\
\text { activities at a } \\
\text { small scale and } \\
\text { policymaking }\end{array}$} \\
\hline & · Workers lay off & $\begin{array}{l}\text { Payment to } \\
\text { workers for } \\
\text { running their } \\
\text { livelihood }\end{array}$ & $\begin{array}{c}\text { Social, economic, } \\
\text { political, } \\
\text { psychological } \\
\text { imbalance in society }\end{array}$ & \\
\hline \multirow{3}{*}{ Food safety } & $\begin{array}{l}\text { P Prominent } \\
\text { concern about } \\
\text { food safety for } \\
\text { non-vegetarian } \\
\text { products }\end{array}$ & $\begin{array}{l}\cdot \text { Need to } \\
\text { strengthen food } \\
\text { safety standards }\end{array}$ & $\begin{array}{l}\text { - Prominent concern } \\
\text { about food safety for } \\
\text { non-vegetarian } \\
\text { products }\end{array}$ & $\begin{array}{l}\text {. Rigorous } \\
\text { research on food } \\
\text { safety is needed } \\
\text { for managing wet } \\
\text { market and non- } \\
\text { vegetarian food } \\
\text { products }\end{array}$ \\
\hline & $\begin{array}{l}\text { - Issues with the } \\
\text { cross- } \\
\text { contamination of } \\
\text { fruits and } \\
\text { vegetables }\end{array}$ & $\begin{array}{l}\text { Promotion of } \\
\text { hygiene and } \\
\text { safety while } \\
\text { handling foods }\end{array}$ & $\begin{array}{l}\text { - Issues with the } \\
\text { cross-contamination } \\
\text { of fruits and } \\
\text { vegetables }\end{array}$ & $\begin{array}{l}\text { · Awareness } \\
\text { campaigns for } \\
\text { customers by the } \\
\text { agri-food sector } \\
\text { and govt. } \\
\text { agencies }\end{array}$ \\
\hline & & $\begin{array}{l}\text { - Awareness } \\
\text { campaigns for } \\
\text { customers by the } \\
\text { agri-food sector } \\
\text { and govt. } \\
\text { agencies }\end{array}$ & & \\
\hline
\end{tabular}

\subsection{Processing and Packaging}

Food processing and packaging, the vital linkages between two pillars of a nation's economy (agriculture and industry), are experiencing both positive and negative impacts due to COVID-19. The demand for shelf-stable food products such as instant noodles, flour, edible oils, cookies, snacks, etc., has gone up exponentially because of these products' hoarding for survival during the crisis. Given limited relaxations to processed food manufacturers, the MNCs like ITC, Britannia, Parle, Nestle, and PepsiCo serves as a means of livelihood for about 1.3 billion people. However, in the coming future, all agri-food processing industries might get virtually stopped due to a deficiency of raw materials, packaging resources, and mobilized labor (Forsido et al., 2020). There is a need to remove the hurdle of different stages of FSCs and take advantage of this opportunity for uplifting the production and circulation of shelfstable food products. This will further balance the food insecurity, economic crisis, and employment opportunities. However, some other allied sectors in food processing, including 
midstream MSMEs, are still under threat and are more susceptible to labor shortages. Disruption in the workforce availability and risk of viral infection has also disturbed the whole downstream dairy processing and circulation networks. The egg, fish, meat, and chicken processing sector is under massive loss due to the claim of the zoonotic nature of COVID-19. Approximately a loss of INR 22.5 million is observed because of rumors regarding the poultry and meat industries. An INR 100 per bird was released through an official memorandum to support such farmers (Food and Agriculture Organization, 2020). Some other influences on processing and packaging are enlisted in Table 3.

Table 3. Effects and remedial strategies: Processing and Packaging

\begin{tabular}{|c|c|c|c|c|}
\hline Factors & Short-term impact & $\begin{array}{l}\text { Remedial } \\
\text { strategies }\end{array}$ & Long-term impact & Remedial strategies \\
\hline \multirow[b]{2}{*}{$\begin{array}{l}\text { Shelf-stable } \\
\text { products }\end{array}$} & \multirow[b]{2}{*}{$\begin{array}{l}\text { The major positive } \\
\text { impact of COVID-19 } \\
\text { is the increased } \\
\text { demand for shelf- } \\
\text { stable products }\end{array}$} & \multirow{2}{*}{$\begin{array}{l}\text { - Increased } \\
\text { production } \\
\text { capacity and } \\
\text { strengthening the } \\
\text { supply chains } \\
\text { along with utmost } \\
\text { safety is of primary } \\
\text { importance for } \\
\text { shelf-stable } \\
\text { products currently }\end{array}$} & & $\begin{array}{c}\text { - Food safety training of } \\
\text { workers }\end{array}$ \\
\hline & & & $\begin{array}{l}\text { Given the high demand, } \\
\text { there may be a lack of } \\
\text { raw produce and } \\
\text { packaging material }\end{array}$ & $\begin{array}{l}\text { - Establishing SMEs in } \\
\text { different parts of the } \\
\text { country to ensure a } \\
\text { regular supply of raw } \\
\text { produce }\end{array}$ \\
\hline \multirow{5}{*}{ Dairy industry } & $\begin{array}{c}\text { Decreased } \\
\text { demand for milk } \\
\text { byproducts }\end{array}$ & $\begin{array}{c}\text { Promotion of } \\
\text { dairy processing, } \\
\text { especially raw-milk } \\
\text { products }\end{array}$ & $\begin{array}{l}\text { - Lack of demand will } \\
\text { affect the farmers } \\
\text { indulged in raw-milk } \\
\text { production }\end{array}$ & $\begin{array}{l}\text { Processing of surplus } \\
\text { milk into other products } \\
\text { having longer shelf-life }\end{array}$ \\
\hline & $\begin{array}{l}\text { Trust issues with } \\
\text { perishable dairy } \\
\text { byproducts due to } \\
\text { infection fear }\end{array}$ & $\begin{array}{c}\text { - Rumors should be } \\
\text { avoided }\end{array}$ & $\begin{array}{l}\text { Price hike issues due to } \\
\text { reduced production }\end{array}$ & $\begin{array}{l}\text { - Promoting safe storage } \\
\text { and distribution systems }\end{array}$ \\
\hline & $\begin{array}{l}\text { Restricted sale of } \\
\text { milk despite } \\
\text { increased demand } \\
\text { for raw milk }\end{array}$ & $\begin{array}{l}\text { - Increased } \\
\text { consumption of } \\
\text { dairy byproducts }\end{array}$ & $\begin{array}{c}\text { Increase concern about } \\
\text { food and nutrition } \\
\text { insecurity }\end{array}$ & $\begin{array}{l}\text { Promoting the rebait } \\
\text { and subsidy schemes }\end{array}$ \\
\hline & $\begin{array}{l}\text { - Restriction of milk } \\
\text { processing up to } \\
\text { the semi-processed } \\
\text { products }\end{array}$ & & & $\begin{array}{l}\text { Diversification of food } \\
\text { products }\end{array}$ \\
\hline & $\begin{array}{l}\text { Problems linked } \\
\text { with product } \\
\text { storage and } \\
\text { distribution }\end{array}$ & & & $\begin{array}{l}\text { Strict guidelines from } \\
\text { the competent authority } \\
\text { for dairy products }\end{array}$ \\
\hline \multirow{3}{*}{$\begin{array}{l}\text { Meat and Fish } \\
\text { processing } \\
\text { industry }\end{array}$} & $\begin{array}{l}\text { - Low demand due } \\
\text { to infection fear }\end{array}$ & $\begin{array}{l}\text {-Allied businesses } \\
\text { should opt for safe } \\
\text { supply and } \\
\text { processing } \\
\text { practices }\end{array}$ & $\begin{array}{l}\text { The collapsing of allied } \\
\text { businesses viz. fish, } \\
\text { poultry, meat, etc. }\end{array}$ & $\begin{array}{l}\text { Promotion of food } \\
\text { processing to make it } \\
\text { available through years } \\
\text { and safe for } \\
\text { consumption. }\end{array}$ \\
\hline & $\begin{array}{l}\text { Vanishing of non- } \\
\text { vegetarian } \\
\text { products from the } \\
\text { market }\end{array}$ & $\begin{array}{l}\text { Search for } \\
\text { additional options } \\
\text { like food } \\
\text { processing }\end{array}$ & Unemployment & $\begin{array}{l}\cdot \text { Need for market } \\
\text { diversification and govt. } \\
\text { incentive schemes }\end{array}$ \\
\hline & $\begin{array}{l}\text { - Reduction in } \\
\text { supply to hotels, } \\
\text { restaurants, small } \\
\text { shops, etc. }\end{array}$ & $\begin{array}{c}\text { Focus on the safe } \\
\text { delivery of } \\
\text { processed } \\
\text { products }\end{array}$ & $\begin{array}{l}\text { - Increased social and } \\
\text { economic pressure }\end{array}$ & \\
\hline
\end{tabular}




\subsection{Distribution and Marketing}

Distribution and marketing, agents to align the demand \& supply, will be a hard hit due to many ups and downs in AFSCs, and several players in AFSCs have withdrawn from the food trade as a result of the pressure on logistics services. This kind of disturbance in the downstream MSMEs leads to a shortage of food, increased demand and price, and increased unemployment (Farias and Gomes, 2020; Singh et al., 2021). Usually, the supplier plans for an anticipated rise in customer demand on special occasions, but, unfortunately, the rapid and unpredictable increase in demand across critical categories have produced short-run outflows for the whole food distribution network designed for just-in-time development and delivery systems (Mussell et al., 2020). On the other hand, concerning the supply-side, there comes a hurdle in the food supply and trade slowdown. The producers of coffee are unable to sell it in the state of Karnataka, India's largest coffee-producing province, owing to the blockade in the supply chain, and tons of processed coffee worth USD 52 million is stacked up in warehouses. Hence, there is a need to find more efficient distribution options for small FSCs so that farmers can deliver their food quickly (Todorovic et al., 2018). However, a few such innovations are already in practice, such as Kerala's state is using mobile vegetable trucks to provide doorstep delivery of fruits and vegetables. But, this is a temporary base solution for short-run problems. Some other issues with probable remedies regarding distribution and marketing in FSCs are mentioned in Table 4.

Table 4. Effects and remedial strategies: Distribution and Marketing

\begin{tabular}{|c|c|c|c|c|}
\hline Factors & $\begin{array}{c}\text { Short-term } \\
\text { impact }\end{array}$ & Remedial strategies & $\begin{array}{l}\text { Long-term } \\
\text { impact }\end{array}$ & Remedial strategies \\
\hline \multirow{12}{*}{$\begin{array}{l}\text { Demand- } \\
\text { side } \\
\text { aspects }\end{array}$} & \multirow{3}{*}{$\begin{array}{l}\text { - Increased food } \\
\text { prices }\end{array}$} & $\begin{array}{l}\text { Restriction on } \\
\text { hoarding }\end{array}$ & $\begin{array}{c}\text { Accessibility of } \\
\text { food to needy } \\
\text { people }\end{array}$ & $\begin{array}{l}\text { - Restriction on } \\
\text { hoarding }\end{array}$ \\
\hline & & $\begin{array}{l}\text { - Creating awareness } \\
\text { regarding the } \\
\text { availability of sufficient } \\
\text { stock }\end{array}$ & - Food insecurity & $\begin{array}{l}\text { - Proper sanitation at } \\
\text { each level of AFSCs }\end{array}$ \\
\hline & & - Monitoring the price & & $\begin{array}{l}\text { - Apt distribution of } \\
\text { food items }\end{array}$ \\
\hline & \multirow{2}{*}{$\begin{array}{l}\text { Recession in the } \\
\text { restaurant and } \\
\text { café businesses }\end{array}$} & $\begin{array}{c}\text {. Rebate/exemption in } \\
\text { taxes }\end{array}$ & \multirow{2}{*}{$\begin{array}{l}\text { Recession in the } \\
\text { restaurant and } \\
\text { café businesses }\end{array}$} & $\begin{array}{c}\text { - Rebate/exemption in } \\
\text { taxes }\end{array}$ \\
\hline & & $\begin{array}{l}\text { Promoting online } \\
\text { delivery systems }\end{array}$ & & $\begin{array}{l}\text { Promoting online } \\
\text { delivery systems }\end{array}$ \\
\hline & $\begin{array}{c}\text { Income loss and } \\
\text { increased } \\
\text { unemployment }\end{array}$ & $\begin{array}{l}\text { Strategies to get } \\
\text { people engaged in } \\
\text { other roles like food } \\
\text { distribution }\end{array}$ & \multirow{3}{*}{$\begin{array}{c}\text { Income loss and } \\
\text { increased } \\
\text { unemployment }\end{array}$} & $\begin{array}{l}\text { Focus on more food } \\
\text { production }\end{array}$ \\
\hline & $\begin{array}{c}\text { Shortage of food } \\
\text { leading to the } \\
\text { crisis }\end{array}$ & $\begin{array}{c}\text { - Search for alternate } \\
\text { market }\end{array}$ & & - Promoting the SMEs \\
\hline & & & & $\begin{array}{l}\text { Integration of the } \\
\text { private sector }\end{array}$ \\
\hline & - Lack of export & \multirow{2}{*}{$\begin{array}{c}\text { Focus on import and } \\
\text { export policies }\end{array}$} & - Lack of export & \multirow{2}{*}{$\begin{array}{l}\text { Trade and market } \\
\text { diversification }\end{array}$} \\
\hline & $\begin{array}{l}\text { - Foreign currency } \\
\text { loss }\end{array}$ & & $\begin{array}{l}\text { · Foreign currency } \\
\text { loss }\end{array}$ & \\
\hline & \multirow{2}{*}{$\begin{array}{c}\text { Reduced demand } \\
\text { for specific food } \\
\text { items }\end{array}$} & $\begin{array}{c}\text { Need for creating } \\
\text { awareness }\end{array}$ & \multirow{2}{*}{$\begin{array}{l}\text { - Reduced } \\
\text { demand for } \\
\text { specific food } \\
\text { items }\end{array}$} & $\begin{array}{c}\text { Need for creating } \\
\text { awareness }\end{array}$ \\
\hline & & $\begin{array}{c}\text { - Can also be focused } \\
\text { on export }\end{array}$ & & $\begin{array}{c}\text { - Can also be focused } \\
\text { on export }\end{array}$ \\
\hline
\end{tabular}


Agri-food supply chain and disruptions due to COVID-19: effects and strategies

\begin{tabular}{|c|c|c|c|c|}
\hline Factors & $\begin{array}{l}\text { Short-term } \\
\text { impact }\end{array}$ & Remedial strategies & $\begin{array}{l}\text { Long-term } \\
\text { impact }\end{array}$ & Remedial strategies \\
\hline \multirow{10}{*}{$\begin{array}{l}\text { Supply- } \\
\text { side } \\
\text { aspects }\end{array}$} & $\begin{array}{l}\text { Trade slows down } \\
\text { due to restricted } \\
\text { movement }\end{array}$ & $\begin{array}{c}\text { Expansion of market } \\
\text { to remote areas }\end{array}$ & · Food shortage. & $\begin{array}{c}\text {. NGOs and } \\
\text { cooperatives can play a } \\
\text { crucial role. }\end{array}$ \\
\hline & \multirow[t]{2}{*}{$\begin{array}{l}\text { Problems } \\
\text { associated with } \\
\text { the supply of agri- } \\
\text { food products due } \\
\text { to import issues }\end{array}$} & $\begin{array}{c}\text { Collaboration among } \\
\text { different government } \\
\text { bodies and R\&D centers }\end{array}$ & $\begin{array}{l}\text { Problems } \\
\text { associated with } \\
\text { the supply of agri- } \\
\text { food products } \\
\text { due to import } \\
\text { issues }\end{array}$ & $\begin{array}{l}\text { Focus on the import of } \\
\text { essential commodities }\end{array}$ \\
\hline & & $\begin{array}{c}\cdot \text { Redesigning of } \\
\text { import/export policies }\end{array}$ & - Food shortage & $\begin{array}{l}\text { - Redesigning the } \\
\text { import/export policies }\end{array}$ \\
\hline & $\begin{array}{l}\text { Shortage of food } \\
\text { in urban areas due } \\
\text { to movement } \\
\text { restrictions }\end{array}$ & $\begin{array}{l}\text { Strengthening the } \\
\text { already working } \\
\text { agencies and } \\
\text { cooperatives }\end{array}$ & \multirow{3}{*}{$\begin{array}{c}\text { Risk of } \\
\text { increasing } \\
\text { infection leads to } \\
\text { food shortage }\end{array}$} & $\begin{array}{l}\text { · Ensuring safe and } \\
\text { continuous movement } \\
\text { for public }\end{array}$ \\
\hline & \multirow[t]{2}{*}{$\begin{array}{c}\text { Psychological } \\
\text { problems }\end{array}$} & $\begin{array}{l}\text { Focusing on } \\
\text { employment }\end{array}$ & & $\begin{array}{l}\cdot \text { Redesigning the } \\
\text { marketing and food } \\
\text { distribution systems }\end{array}$ \\
\hline & & & & $\begin{array}{l}\text { Specialized food } \\
\text { transporters }\end{array}$ \\
\hline & \multirow{2}{*}{$\begin{array}{l}\text { Reduced supply } \\
\text { of food and } \\
\text { adulteration } \\
\text { leading to food } \\
\text { price hiking }\end{array}$} & $\begin{array}{l}\text { Designing the policies } \\
\text { for food storage and } \\
\text { distribution }\end{array}$ & $\begin{array}{l}\text { Accessibility of } \\
\text { food to needy } \\
\text { people }\end{array}$ & $\begin{array}{l}\text { - Efficient distribution of } \\
\text { food items }\end{array}$ \\
\hline & & $\begin{array}{l}\text { - Regular checks on } \\
\text { adulterations }\end{array}$ & · Food insecurity & $\begin{array}{l}\text { maintaining sanitation } \\
\text { at each level through } \\
\text { the supply chains }\end{array}$ \\
\hline & \multirow{2}{*}{$\begin{array}{l}\text { Reduced supply } \\
\text { of specific food } \\
\text { items }\end{array}$} & - Awareness campaigns & \multirow{2}{*}{$\begin{array}{c}\text { - Reduced supply } \\
\text { of particular food } \\
\text { items }\end{array}$} & - Awareness campaigns \\
\hline & & $\begin{array}{l}\text { Focus on stable } \\
\text { transportation }\end{array}$ & & $\begin{array}{l}\text { Focus on stable } \\
\text { transportation }\end{array}$ \\
\hline
\end{tabular}

\subsection{Consumption}

India's AFSCs concerning procured food market and consumption are enormous, and the urban people consume approximately 60 percent of India's food. All food eaten in these areas is purchased because nearly all the urban residents are net food buyers. However, out of the rest 40 percent of food, about 80 percent is purchased (Reardon et al., 2020). This much large share of purchased food, in overall food intake, decreases day by day due to the declining earning and food consumption patterns. About 85 and 53 percent of the workforce do not have paid jobs in rural and urban areas, respectively, and 46 percent of the salaried job staff do not get any paid leave. Over 70 percent of employees work without legal agreements. Overall, nearly 90 percent of all families in India would encounter a significant drop in income in the coming months (Abhishek et al., 2020). As a result, the restaurants are getting closed, and food \& nutritional insecurity is increasing day by day. Further, a shift in purchasing and consumption patterns from local markets to supermarkets is now a rising question for society. Short FSCs and local produce may be a possible solution to these questions (Cappelli and Cini, 2020; Mayurnikova et al., 2020). Additionally, the call for green agriculture products should be encouraged. It further helps in developing the green agricultural product supply chain which strengthens the relation between agricultural product suppliers and urban residents ( $Y u$ and Khan, 2021). However, worth noting point for such pandemic situations, poor people are getting rice, pulses, cooking gas, etc., free for a minimum of three months under Pradhan Mantri Garib Kalyan Yojana (PMGKY, India). Amid COVID-19, the defense food research laboratory (DFRL) is working around the clock for feeding nutritious meals, particularly to healthcare professionals across India. The Karnataka government is effectively providing 1 million meals to the starving poor people in Bengaluru with the aid of a food delivery app developed by young engineers. Private firms such as SRK and Wipro have funded about 60,000 servings per day in the government canteens to feed the needy (Food and Agriculture Organization, 2020), and there are numerous other examples in this line. There requires concise attention regarding the impacts and policies for getting out of this pandemic's unwanted situation, as mentioned in Table 5. 
Table 5. Effects and remedial strategies: Consumption

\begin{tabular}{|c|c|c|c|c|}
\hline Factors & $\begin{array}{l}\text { Short-term } \\
\text { impact }\end{array}$ & Remedial strategies & $\begin{array}{l}\text { Long-term } \\
\text { impact }\end{array}$ & Remedial strategies \\
\hline \multirow{2}{*}{$\begin{array}{l}\text { Closed } \\
\text { restaurants }\end{array}$} & \multirow{2}{*}{$\begin{array}{l}\cdot \text { Food } \\
\text { availability } \\
\text { issues }\end{array}$} & $\begin{array}{c}\text { - Ensuring food } \\
\text { safety throughout } \\
\text { AFSC }\end{array}$ & \multirow{2}{*}{$\begin{array}{l}\text { Permanent } \\
\text { closure of many } \\
\text { restaurants }\end{array}$} & $\begin{array}{c}\text { Support from } \\
\text { government agencies }\end{array}$ \\
\hline & & $\begin{array}{l}\text { Regular monitoring } \\
\text { of workers }\end{array}$ & & $\begin{array}{l}\text { Searching for } \\
\text { alternate options }\end{array}$ \\
\hline \multirow{2}{*}{$\begin{array}{c}\text { Food } \\
\text { consumption } \\
\text { pattern }\end{array}$} & \multirow{2}{*}{$\begin{array}{l}\text { A remarkable } \\
\text { shift in food } \\
\text { consumption } \\
\text { patterns }\end{array}$} & \multirow{2}{*}{$\begin{array}{l}\text { Food businesses } \\
\text { should try to capture } \\
\text { the new pattern }\end{array}$} & \multirow{2}{*}{$\begin{array}{l}\text { A significant } \\
\text { shift in food } \\
\text { consumption } \\
\text { patterns }\end{array}$} & $\begin{array}{l}\text { Focus on new \& } \\
\text { customized food } \\
\text { products }\end{array}$ \\
\hline & & & & $\begin{array}{l}\text { Food businesses } \\
\text { should try to capture } \\
\text { the new pattern }\end{array}$ \\
\hline \multirow[b]{2}{*}{$\begin{array}{l}\text { Food and } \\
\text { nutrition } \\
\text { insecurity }\end{array}$} & \multirow{2}{*}{$\begin{array}{l}\text { - Extensive } \\
\text { effect on } \\
\text { weaker sections } \\
\text { of the } \\
\text { community }\end{array}$} & $\begin{array}{c}\cdot \text { Creation of } \\
\text { emergency shelter }\end{array}$ & $\begin{array}{l}\text { Extensive effect } \\
\text { on weaker } \\
\text { sections of the } \\
\text { community }\end{array}$ & $\begin{array}{l}\text { Creating } \\
\text { employment } \\
\text { opportunities }\end{array}$ \\
\hline & & $\begin{array}{l}\text { Need for resources } \\
\text { mobilization }\end{array}$ & $\begin{array}{l}\text { The enhanced } \\
\text { dependency of } \\
\text { the public to } \\
\text { seek support } \\
\text { from govt. } \\
\text { bodies }\end{array}$ & $\begin{array}{l}\text { Strengthening small } \\
\text { scale businesses, } \\
\text { particularly in agri- } \\
\text { food processing }\end{array}$ \\
\hline \multirow[b]{2}{*}{$\begin{array}{l}\text { Effect on the } \\
\text { customer }\end{array}$} & \multirow{2}{*}{$\begin{array}{l}\text { - Income-loss } \\
\text { leading to the } \\
\text { reduced } \\
\text { purchasing } \\
\text { power of public }\end{array}$} & $\begin{array}{l}\text { Cash flow for the } \\
\text { smooth functioning } \\
\text { of agri-food markets }\end{array}$ & \multirow{2}{*}{$\begin{array}{l}\text { - Income-loss } \\
\text { leading to the } \\
\text { reduced } \\
\text { purchasing } \\
\text { power of public }\end{array}$} & $\begin{array}{l}\text {. Cash flow for the } \\
\text { smooth functioning } \\
\text { of agri-food markets }\end{array}$ \\
\hline & & $\begin{array}{l}\text { - Safe and continuous } \\
\text { delivery of food } \\
\text { products throughout } \\
\text { AFSCs }\end{array}$ & & $\begin{array}{c}\text { - Safe and continuous } \\
\text { delivery of food } \\
\text { products throughout } \\
\text { AFSCs Creating } \\
\text { employment options }\end{array}$ \\
\hline \multirow{3}{*}{ Increase in price } & \multirow{3}{*}{$\begin{array}{l}\text { Price hicks due } \\
\text { to restricting } \\
\text { movements and } \\
\text { storage issues }\end{array}$} & $\begin{array}{l}\text { - Disturbance in } \\
\text { AFSCs needs } \\
\text { effective } \\
\text { management }\end{array}$ & \multirow{3}{*}{$\begin{array}{l}\text { Scarcity of food } \\
\text { due to lagging } \\
\text { systems }\end{array}$} & $\begin{array}{l}\text { Disturbance in } \\
\text { AFSCs needs } \\
\text { effective } \\
\text { management }\end{array}$ \\
\hline & & $\begin{array}{l}\text { Proper monitoring } \\
\text { of the wholesale and } \\
\text { retail market }\end{array}$ & & $\begin{array}{l}\text { Promotion and } \\
\text { funding to local agri- } \\
\text { food processing units }\end{array}$ \\
\hline & & $\begin{array}{l}\text { Strengthening the } \\
\text { doorstep delivery } \\
\text { systems }\end{array}$ & & \\
\hline \multirow{4}{*}{$\begin{array}{l}\text { Psychological } \\
\text { effect }\end{array}$} & $\begin{array}{l}\text { - Reduced } \\
\text { consumption of } \\
\text { high-value food } \\
\text { products }\end{array}$ & $\begin{array}{l}\text { - Motivating the } \\
\text { producers and } \\
\text { farmers }\end{array}$ & $\begin{array}{c}\text { Reduced } \\
\text { consumption of } \\
\text { high-value foods }\end{array}$ & $\begin{array}{l}\text { - Eradicating } \\
\text { confusion about the } \\
\text { virus and brake on } \\
\text { rumors }\end{array}$ \\
\hline & $\begin{array}{c}\cdot \text { Risk of } \\
\text { consumers and } \\
\text { producers }\end{array}$ & $\begin{array}{l}\text { - Awareness } \\
\text { campaigns }\end{array}$ & $\begin{array}{l}\cdot \text { Risk of } \\
\text { consumers and } \\
\text { producers }\end{array}$ & $\begin{array}{c}\text { - The public mind-set } \\
\text { need to shift to other } \\
\text { issues }\end{array}$ \\
\hline & $\begin{array}{l}\cdot \text { Lack of } \\
\text { inspiration }\end{array}$ & & & \\
\hline & $\begin{array}{c}\cdot \text { Fear of } \\
\text { quarantine }\end{array}$ & & & \\
\hline
\end{tabular}

\section{CONCLUSIONS}

The AFSCs and the private sector's fusion has set India as one of the fastest rising agrifood economies globally. Given the aforesaid features of Indian FSCs and the nationwide 
lockdown, it is concluded that the COVID-19 pandemic has its long-term effects on the Indian agri-food sector. This paper addresses the demand and supply side of Indian AFSCs and probable short-term and long-term impacts and remedial strategies. The government authorities and NGOs are trying hard to handle this uninvited guest and getting AFSCs back again on the right track. Despite the current pandemic, studies suggest that there will be no acute food deficit in the market for the coming few months. However, there may come a stage of the recession just after this disaster due to disturbances in different farmer end activities, industrial processing, and the linking AFSCs. Therefore, the entire agri-food sector needs unprecedented strategies and policies because the concept of 'work from home' is not applicable here, and life cannot move even a single step without food.

\subsection{Limitations and future scope}

The paper offers a perspective of the future AFSCs, viewing the current scenario and information available to date. Although this is a novel area, it may take enormous time to fully assess the current pandemic (COVID-19) effect on agri-food and its allied sectors. Numerous technological innovations will likely occur in the coming years. Future research, innovations, policies, machinery, etc., would help farmers better cope with such pandemic and offer an efficient AFSCs while also making the agri-food sector more productive and more attractive for the coming generations. Thus, there seems to be an infinite scope of research associated with the agri-food sector and making this a business of interest and full of profit through technological innovations.

\section{ACKNOWLEDGEMENTS}

The authors are thankful to the National Institute of Food Technology Entrepreneurship and Management, Kundli, Sonepat (Haryana), India, for providing the infrastructural and other supports to conduct this research work smoothly.

\section{REFERENCES}

Abhishek, Bhamoriya, V., Gupta, P. et al. (2020), "India's Food System in the Time of Covid-19", Economic and Political Weekly, Vol. 15, pp. 12-4.

Belhadi, A., Kamble, S.S., Khan, S.A.R. et al. (2020), "Infectious Waste Management Strategy during COVID19 Pandemic in Africa: an Integrated Decision-Making Framework for Selecting Sustainable Technologies", Environmental Management, Vol. 66, No. 6, pp. 1085-104.

Bhatia, M. and Janardhana, G.M. (2020), "Agriculture supply chain management - an operational perspective", Brazilian Journal of Operations \& Production Management, Vol. 17, No. 4, pp. e2020978. http://dx.doi.org/10.14488/BJOPM.2020.043.

Cappelli, A. and Cini, E. (2020), "Will the COVID-19 pandemic make us reconsider the relevance of short food supply chains and local productions", Trends in Food Science \& Technology, Vol. 99, pp. 566-7.

Carberry, A. and Padhee, A.K. (2020), “Containing COVID-19 impacts on Indian agriculture, available at: https://www.icrisat.org/containing-covid19-impacts-on-indian-agriculture/ (accessed 12 May 2020).

Chand, R., Srivastava, S.K. and Singh, J. (2017), "Changes in rural economy of India, 1971 to 2012 lessons for job-led growth", Economic and Political Weekly, Vol. 52, pp. 64-71.

D'Souza, A., Mishra, A.K. and Hirsch, S. (2020), "Enhancing food security through diet quality: the role of non-farm work in rural India", Agricultural Economics (United Kingdom), Vol. 51, No. 1, pp. 95-110.

Farias, D.P. and Gomes, M.G.S. (2020), "COVID-19 outbreak: What should be done to avoid food shortages?", Trends in Food Science \& Technology, Vol. 102, pp. 291-2. http://dx.doi.org/10.1016/j.tifs.2020.06.007.

Food and Agriculture Organization (2019), "Food loss and food waste", available at: http://www.fao.org/food-loss-and-food-waste/en (accessed 8 May 2020).

Food and Agriculture Organization (2020), “Local food systems and COVID-19: a glimpse on India's responses", available ht: http://www.fao.org/in-action/food-for-citiesprogramme/news/detail/en/c/1272232 (accessed 12 May 2020). 
Forsido, S.F., Mitiku, F., Lemessa, F. et al. (2020). Covid-19 probable impacts on Ethiopian agriculture and potential mitigation and adaptation measures: no food-no health-no life. Jimma, Ethiopia, 1-79. available https://www.ju.edu.et/sites/default/files/Covid19\%20impact\%20on\%20Eth\%20Agri\%20and\%20mitig ation\%2023.04.20_final.pdf (accessed 5 May 2020).

Galanakis, C.M. (2020), "The Food Systems in the Era of the Coronavirus (COVID-19) Pandemic Crisis", Foods, Vol. 9, No. 523, pp. 1-10.

Hobbs, J.E. (2020), "Food supply chains during the COVID-19 pandemic", Canadian Journal of Agricultural Economics. http://dx.doi.org/10.1111/cjag.12237.

Ivanov, D. and Dolgui, A. (2020), "Viability of intertwined supply networks: extending the supply chain resilience angles towards survivability. A position paper motivated by COVID-19 outbreak", International Journal of Production Research, Vol. 58, No. 10, pp. 2904-15.

Kamble, S.S. and Mor, R.S. (2021), "Food supply chains and COVID-19: a way forward", Agronomy Journal, pp. 1-3. http://dx.doi.org/10.1002/agj2.20515.

Khan, S.A.R. and Yu, Z. (2019), Strategic Supply Chain Management (pp. 1-290), Springer Nature Switzerland AG.

Khan, S.A.R., Yu, Z., Golpîra, H. et al. (2020), "A state-of-the-art review and meta-analysis on sustainable supply chain management: future research directions", Journal of Cleaner Production. http://dx.doi.org/10.1016/j.jclepro.2020.123357.

Larue, B. (2020), "Labour issues and COVID-19", Canadian Journal of Agricultural Economics. Vol. 68, No. 2, pp. 231-237. http://dx.doi.org/10.1111/cjag.12233.

Mayurnikova, L.A., Koksharov, A.A. and Krapiva, T.V. (2020), "Food safety practices in catering during the coronavirus COVID-19 pandemic", Foods and Raw Materials, Vol. 8, No. 2, pp. 197-203.

Mor, R.S., Bhardwaj, A. and Singh, S. (2018). "A structured literature review of the Supply Chain practices in Food Processing Industry", Proceedings of the International Conference on Industrial Engineering and Operations Management Bandung, Indonesia, pp. 588-599.

Mussell, A., Bilyea, T. and Hedley, D. (2020). Agri-Food Supply Chains and Covid-19: balancing resilience and vulnerability. Agri-Food Economic Systems, 1-6. available at: www.agrifoodecon.ca (accessed 11 May 2020).

Phillipson, J., Gorton, M., Turner, R. et al. (2020), "The COVID-19 pandemic and its implications for rural economies", Sustainability, Vol. 12, No. 3973, pp. 1-9.

Ranjith, P.V. and Varma, A.J. (2020), "COVID 19-Indian scenario, challenges and possible revival strategies", Purakala, Vol. 31, No. 4, pp. 1834-42.

Reardon, T., Mishra, A., Nuthalapati, C.S.R. et al. (2020), "COVID-19's disruption of India's transformed food supply chains", Economic and Political Weekly, Vol. 55, No. 18, pp. 1-4.

Sharma, R., Shishodia, A., Kamble, S., et al. (2020). Agriculture supply chain risks and COVID-19: mitigation strategies and implications for the practitioners. International Journal of Logistics Research and Applications, 1-27, https://doi.org/10.1080/13675567.2020.1830049.

Singh, S., Kumar, R., Panchal, R. et al. (2021), "Impact of COVID-19 on logistics systems and disruptions in food supply chain", International Journal of Production Research, Vol. 59, No. 7, pp. 1-16. http://dx.doi.org/10.1080/00207543.2020.1792000.

Stauffer, J.M., Pedraza-Martinez, A.J., Yan, L.L. et al. (2018), "Asset supply networks in humanitarian operations: a combined empirical-simulation approach", Journal of Operations Management, Vol. 63, No. 1, pp. 44-58.

Todorovic, V., Maslaric, M., Bojic, S. et al. (2018), "Solutions for more sustainable distribution in the short food supply chains", Sustainability, Vol. 10, No. 3481, pp. 1-27.

Toppo, A. (2020). “Covid-19: Bharatiya Kisan Union Demands Rs. 1.5-lakh Crore Relief Package for Farm Sector", available at: https://krishijagran.com/agriculture-world/covid-19-bharatiya-kisan-uniondemands-rs-15-lakh-crore-relief-package-for-farm-sector (accessed 6 May 2020).

Troskie, D.P. (2020), "Impact of COVID-19 on Agriculture and Food in the Western CAPE Working Document (Version-2)", available at: https://www.hortgro.co.za/wpcontent/uploads/docs/2020/03/agricultural-scenariosc.pdf (accessed 4 May 2020). 
UN News, (2020), "COVID-19: The global food supply chain is holding up, for now", available at: https://news.un.org/en/story/2020/04/1061032 (accessed 3 April 2020).

World Health Organization, (2020). "Coronavirus disease (COVID-19) situation report-108", available at: https://www.who.int/docs/default-source/coronaviruse/situationreports/20200507covid-19-sitrep108.pdf?sfvrsn=44cc8ed8_2 (accessed 7 May 2020).

Yahia, E.M., Fonseca, J.M. and Kitinoja, L. (2019). "Postharvest Losses and Waste”, in E.M. Yahia (Ed.), Postharvest Technology of Perishable Horticultural Commodities (pp. 43-69). Woodhead Publishing. https://doi.org/10.1016/B978-0-12-813276-0.00002-X.

Yu, Z. and Khan, S. A. R. (2021). "Evolutionary game analysis of green agricultural product supply chain financing system: COVID-19 pandemic", International Journal of Logistics Research and Applications, 1 21. https://doi.org/10.1080/13675567.2021.1879752.

Yu, Z., Razzaq, A., Rehman, A. et al. (2021), “Disruption in global supply chain and socio-economic shocks: a lesson from COVID-19 for sustainable production and consumption". Operations Management Research, https://doi.org/10.1007/s12063-021-00179-y.

Zurayk, R. (2020), "Pandemic and food security", Journal of Agriculture, Food Systems, and Community Development, Vol. 9, No. 3, pp. 1-5.

Author contributions: Saurabh Sid studied the literature and drafted this manuscript; Rahul S Mor monitored and directed the manuscript preparation; Anupama Panghal, Dinesh Kumar, Vijay Kumar Gahlawat supervised the revisions and content. The final edited manuscript was approved by all authors. 